\title{
On Air: Representing Osing Identity in Community Radio
}

\author{
Windu Bramantio Wisnu Murti, Dien Vidia Rosa ${ }^{1}$ \\ University of Jember \\ dien.fisip@unej.ac.id
}

\begin{abstract}
The purpose of this research is to describe the articulation of Osing's culture on three community radios in Banyuwangi. Understanding language as an identity medium is essential to analyzing underlying cultural dynamics and the crucial vital they play. The Government policy reshaped Osing's identity as an added value to drive regional economic growth. This impacted local, cultural practices. The government created the Osing culture as the primary character used to differentiate them from other cultural practices. Notwithstanding, this research argues that culture is not an entity that can be organized and represented in a monolithic form. Using qualitative methods, this study found that the Osing culture, especially the practice of its language, became a medium of discourse that intertwined with various other cultures. Furthermore, radio has become a space for cultural encounters and a site for cultural submissions that are continually changing and discovering social contexts.
\end{abstract}

Keywords: Osing languages, Osing community radio, Osing representations.

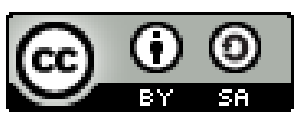

Copyright $\odot 2021$ by Author(s)

This work is licensed under a Creative Commons Attribution-ShareAlike 4.0

International License. All writings published in this journal are personal views of the authors and do not represent the views of this journal and the author's affiliated institutions.

\section{HOW TO CITE:}

Murti, Windu B W \& Dien Vidia Rosa. "On Air: Representing Osing Identity in Community Radio"(2021) l:1 Contemporary Sociological Issues 1-16.

Submitted :October 9, 2020

Revised :November 22, 2020
Accepted

Publish
:January 2, 2021

: February 5, 2021

${ }^{1}$ Correspondent Author 


\section{INTRODUCTION}

In every cultural festival the presence of the Banyuwangi local government is almost always acts as the organizer. The local government is positioned as the guest of honor alongside cultural leaders who hold traditional ceremonies. This description of the identity of Osing which was reshaped by the local government is to eliminate the bad stigma regarding Banyuwangi in the past ${ }^{2}$. The chosen slogan "The Sunrise of Java", has become the message conveyed to the public that Banyuwangi has woken through tourism and the Osing culture.

The emergence of the spirit to articulate culture in the economic space is part of the development movement in Banyuwangi ${ }^{3}$. Media development is a necessity following the existence of a cultural economy setting in celebration of Osing's identity. In the context of this research, radio becomes a pressure point for the presence of social spaces that celebrate identity in a dialogical manner. The dialogue model is not new in communicating on radio, but for community radio researchers in Banyuwangi it displays the plurality of Osing's culture.

For the people of Banyuwangi, radio that displays the cultural character of Osing has a special place. Conventional radios such as Bintang Tenggara FM, Gandrung FM, Tawang Alun FM and Mandala FM have Osing gending programs. Audiences can get involved by sending a message to be read out by the broadcaster, through live telephone, or by directly visiting a radio and asking for the Osing song to be played. In the Radio context, these three options of sending message require to use the Osing language. It is interesting to see social relations displayed on the radio, for example, an Osing song karaoke program involving the audience via telephone.

Sound or tone limitations seem to be put aside to emphasize the particularity of the Osing culture shared by the audience. Freud alludes to the internal aspects of the subject which are understood as instinctive or instinctive in relation to desire ${ }^{4}$. The Freudian conception of desire that appears through language becomes the entry point for the imagination of the form of identity, mediated by the subject and its social setting. With this assumption, parole represents the dominant identity of a particular area and the language forms used can present variants in Osing culture.

The conflict began to emerge when Banyuwangi Radio Broadcast Network (JRSB) discovered a number of 'illegal' radio communities. The JRSB reported those communitties on allegations of interfering with flights, misusing radio frequencies and

\footnotetext{
${ }^{2}$ Actor Relations in The Discourse Space of Cultural Policies in Banyuwangi

MH Makmur, A Taufiq - KARSA: Journal of Social and Islamic Culture, 2015 DOI: http://dx.doi.org/10.19105/karsa.v22i2.575

${ }^{3}$ Hery Prasetyo dan Dien Vidia Rosa, "Space For Cultural Articulation: Voising The Local in Commodity Transformation," dalam Rethingking The Human Dignity and Nation Identity: A Review Perspective of Arts and Arts Education (Faculty of Language and Arts Yogyakarta State University, 2014).

${ }^{4}$ E Fromm, The Art ofListening (Kritik Atas Psikoanalisis Sigmund Freud) (Yogyakarta: Immortal Publishing dan Octopus, 2002).
} 
unauthorized ownership. The issue of legality in community radio needs to be underlined as an issue that should be viewed within a cultural economy frame. The establishment which was confirmed by the legality of conventional radio seemed to be shaken by those that relied on the strength of the community. In other words, the struggle for Osing's culture is part of affirming the formal legitimacy that conventional radio has.

Apart from developing an allternative narrative, this study focuses on three Osing community radio stations that are located in the District of Singojuruh namely Adelia FM, in the District of Sempu with Ayu FM, and District of Rogojampi with Javas FM. The deliberate choice of three radio stations in different regions is intended to emphasize the cultural characteristics that differentiate one from another. However, in practice, some Javanese or Madurese is included. This research does not intend to portray the Osing language as autonomous, or even to be thought of as an exclusive cultural system, but rather to describe the spatial plurality of the Osing language.

This community radio has local listeners who are active in its participation to send messages, sing or listen to daily radio 5 . The pattern of intimacy in every conversation is built up because the body is capable of feeling various emotions ${ }^{6}$. The sense of caring among listeners, for example to advise and entertain, to show intimacy or closeness between listeners, is established through community radio. On the other hand, certain things have not been accepted by community radio, namely the cultural and legal legitimacy of Osing. Culturally, they are not considered to have participated in the development of the Osing culture itself. Legally, they have not been granted an official permit.

\section{OSING IN THE HISTORY OF BANYUWANGI : AN ALTERNATIVE IN PUTTING LINGUISTIC PRACTICES}

Banyuwangi became famous with the song Genjer-Genjer, which was created and performed by the original Blambangan artist, Mohammad Arief. Those songs had formed a bad stigma of Banyuwangi in 1965 when there was a political dispute. The name Osing itself is still polemic among Banyuwangi cultural observers.

"It is actually an agreement $(U$ or $O)$, the difference between Osing language and other languages is that there are actually 3 phonology aspects of pronunciation, diptongization (i/ai), patalization (umah/umyah), and glotal (no/nok) ${ }^{7}$

\footnotetext{
${ }^{5}$ Bernard Arps, "Terwujudnya bahasa Using di Banyuwangi dan peranan media elektronik di dalamnya ( selayang pandang, 1970-2009)," Tokyo Research Instituties for Languages And Cultures Of Asia and Africa (ILCAA) Tokyo of Foreign Studies, 2010, 226-45.

${ }^{6} \mathrm{~J}$. A Tachi, Radio Sound As Material Culture In The Home (London: University College London, 1997).

${ }^{7}$ Interview with Mr. Suhalik (Osing Cultural Practioner). Date : 10 March 2020
} 
The phonological process (sound) in the practice of pronouncing the Osing language in everyday life also affects the use of $\mathrm{U}$ or $\mathrm{O}$. In this writing, using Osing with the letter ' $U$ ' was chosen because of the influence of everyday life and transcripts as a source of writing. In the transcript, it is mentioned that the cultural observer Hasan Ali, who has persistently struggled to recognize the Osing language as a new language deliberately chooses to refer to Osing with ' $U$ ' instead of ' $O$ '. . In the development of cultural identity, mention of Osing got a new form when Oseng writing appeared as part of the identity project.

The variations in Osing writing leave problems for discussion. It is necessary to remember that the issue of discussion has become part of the debate of the elite group which seems far removed from how the Osing language lives in the daily life of the community. Agreement on the definite and even standardized form of writing Osing from elite groups is still far from being realized. In fact what can currently be seen is how elite groups use it to form some kind of linguistic exoticization ${ }^{9}$.

As language introduces the concept of a nation, it must be intertwined and able to abstract in a concrete and close to everyday life ${ }^{10}$. So, the use of the Osing language in everyday life becomes a reinforcement of Osing's identity. In connection with the linguistic assumption, the choice of diction in a language such as the Banyuwangi gending is intended to emphasize the issue of social identity.

Umbul-Umbul Blambangan is one of the patriotic songs, however, in the verse of the song the word 'Belambangan' is emphasized more than Banyuwangi. For researchers, the distinction between Blambangan and Banyuwangi becomes two things that represent the cultural meaning inherent in the Blambangan concept. Meanwhile Banyuwangi is more intended to picture a regional identity that is formed administratively. Ben Arps, argues that "Suwarane gendhing Belambangan" is defined as a desire for recognition (2010). As an active verb, the desire for recognition becomes a social imagination that is being contested in linguistic politics in Banyuwangi. In line with this definition, the Osing people prefer to be called Blambangan or Belambangan rather than as Banyuwangi. An important point to emphasize is how linguistic politics should be reflected in technological spaces, especially in the use of community radio.

\section{AMBIGUITY OF OSING COMMUNITY RADIO}

In the slogan The Sun Rise of Java, which regent Anas, who served ten year from 20102020, developed as a new, more dynamic, to prepare Banyuwangi for, and adapt to,

\footnotetext{
${ }^{8}$ Andhika Wahyudiono, "Kajian Bahasa Osing Dalam Modernitas," dalam Eskplorasi Bahasa, Sastra dan Budaya Jawa Timuran (Jember: Universitas Jember, 2018).

9 Prasetyo, Hery., Rosa, Dien Vidia. 2015. (Auto) Exotism (Ke/Pem) Bahasa (an): Reinterpreting The Political Fragmentation of Cultural Space. Dalam, Macaryus, S; Prabowo, DP. (ed). Javanese Pre Congress National Seminar Proceedings VI 2016. Javanese and its Development Perspective. The National Cultural Development Institute, University of Sarjanawiyata Tamansiswa Yogyakarta in collaboration with Yogyakarta Language Center. p. 80-100.

${ }^{10}$ B Anderson, Imagined Communities (Komunitas-Komunitas Terbayang) (Yogyakarta: Insist, 2008).
} 
globalization. As "the sun rising from Java", Banyuwangi was formed as a region that is advanced in culture, has quality citizens and infrastructure that can support social activities. Regional development programs that emphasize the strength of culture are not easy ventures. At the beginning of the policy implementation, many challenges arose from parties. However, the development of the Banyuwangi region is begining to show rapid progress.

The presence of Osing culture in public spaces aims to shape the Banyuwangi community by demonstrating Osing ways of living. Osing's culture is massively explored and attached to practical needs. This commodity culture continues to be promoted as a new icon of Banyuwangi. Without consideration of the cultural authenticity escalation that increases when a culture has become a commodity, it will greatly affect the continuity of these cultural rites, to the point where boredom of culture emerges which is none other than festivalization. In this context, bureaucrats are limited to providing market share and artificially shaping the Osing culture Hery Prasetyo, "Ruang Abstrak Pemangku Adat: Narasi Elite Dan Re-Tradisionalisme Komunitas Using," Jurnal Sosiologi Pendidikan Humanis Volume 2, (2017): 74-87. ${ }^{11}$

On the one hand, the entry of the bureaucracy into the cultural market emerges articulately and contextually. On the other hand, the formation of a new traditional elite does not fully adhere to the role of Osing culture heir genealogy. Even so, they play a role that is almost parallel to that of bureaucrats, by offering Osing's culture to the public as tourist commodity ${ }^{12}$. Borrowing Jameson's thought, Osing's culture is formed of cultural practices that are spread out and not singular, scattered in various forms they emerged from authentic social relations ${ }^{13}$. Behind the government's economic policy there is still a gray area presented by community radio. Community radio with a limited coverage area offers the imagination of Osing's cultural interests .

In the Indonesian context, the radio community originated in the reform era. Radio is an alternative space that can facilitate the expression of cultural criticism. As one of the radio community's pioneer KBR $68 \mathrm{H}$ Jakarta always presents a nuanced editorials community ${ }^{14}$. Exclusive dialogue programs, broadcast segments that intensively discuss the latest issues have become the daily life of this community radio. Another description of the existence of community radio can be found in the historical lines of upheaval in Serbia ${ }^{15}$ and Rwanda ${ }^{16}$.

The existence of community radio in Indonesia, which is at the heart of the middle-lower class society, with the true aim of art, namely to reproduce real life

\footnotetext{
${ }^{11}$ Hery Prasetyo, "Ruang Abstrak Pemangku Adat : Narasi Elite Dan Re-Tradisionalisme Komunitas Using," Jurnal Sosiologi Pendidikan Humanis Volume 2, (2017): 74-87.

${ }^{12}$ H Prasetyo, "Image Hegemonik: Membentuk dan Menciptakan Ruang Reproduksi Kultural," dalam Kebudayaan Osing : Konstruksi, Identitas Dan Pengembangannya (Yogyakarta: Anoegrajek, 2016).

${ }^{13}$ M Sutrisno dan H Putranto, Teori-Teori Kebudayaan (Yogyakarta: Kanisius, 2005).

${ }^{14}$ Edwin Jurriens, From Monologue To Dialogue : Radio And Reform In Indonesia (Leiden: KITLV Press, 2009).

${ }^{15}$ Matthew Collin, Serbia Calling : Kisah Radio B92, Musik Rock' n' roll dan Perlawanan Bawah Tanah dari Beograd (Jakarta: Kantor Berita Radio 68H, 2003).

${ }^{16}$ Linda Kirschke, Gelombang Kematian: Media Pengobar Genosida Rwanda (Jakarta: KataKita, 2004).
} 
phenomena that are of human interest Goenawan Mohamad, Seni Politik Pembebasan.. ${ }^{17}$ What people are interested in is singing, expressing in an orderly and easily accessible manner, no need for cameras or coverage of competent journalists, simply daily rituals that can be repeated.

The existence of Community Radio always displays counter powers. Community radio in Indonesia is not only about social politics, such as fishing community radio in Pangandaran, Community Radio Suara Pangandaran Emergency Recovery, which functions as a medium for dissemination or dissemination of information to the public ${ }^{18}$. Information about the weather, family, and health is included in the broadcast schedule on community radio and it is only natural when the community plays more roles. Especially in terms of disseminating information from listeners, suggestions or criticism of broadcasts. Funding is entirely independent from listeners. In practice, researchers found that community radio had attracted a stigma whereby it was considered an 'illegal' form of media, provocateurs, did not bring any benefits. Unfortunately, this understanding is still attached to the Osing community radio in Banyuwangi.

Community radio is a broadcasting institution that is established, managed, used and owned by the community ${ }^{19}$. The management, use and ownership of the three radios are highly dependent on community participation. Osing community radio emerged with the Gending Osing broadcast program. There are two parts in placing radio listeners only as listeners and placing listeners as a close relationship like family ${ }^{20}$. Osing community radio broadcasters are very flexible and outgoing in delivering broadcasts, it can be seen when broadcasters cleverly build an attractive broadcast atmosphere and read messages fluently in the Osing language.

Community radio is not merely concerned with disseminating information, it should also become an alternative facility for listeners to discuss, to reach a consensus and to develop creative sensitivity within the community ${ }^{21}$. It can also serve as a medium to encourage the creation of similar goals within the community for the establishment of the Osing community radio.

The conflict between community radio and conventional radio in Banyuwangi occurred because one party was deemed to have exploited broadcast frequencies illegally, the establishment of radios which resulted in disruption of flight communication lines and a temporary broadcast permit. Apart from all the polemics that have been generated, community radio is enclaved to maintain the stability of an

\footnotetext{
${ }^{17}$ Goenawan Mohamad, Seni Politik Pembebasan (Yogyakarta: IRCISoD, 2018).

${ }^{18}$ Kokom Komariah, "Pemanfaatan Radio Komunitas Di Masyarakat Nelayan Dalam Melestarikan

Lingkungan Pantai Berbasis Budaya Lokal," Jurnal Visi Komunikasi 13, no. 1 (2014).

${ }^{19}$ Komariah.

${ }^{20}$ Jurriens, From Monologue To Dialogue : Radio And Reform In Indonesia.

${ }^{21}$ Jurriens.
} 
emotion by entering a certain channel but still in a controlled manner ${ }^{22}$. Singing and jokes are an alternative to building an attractive situation on community radio.

\section{COMMUNITY RADIO STORIES}

The three radios at the center of this article are Adelia FM, which was founded in 2011 and is owned by Mrs. Sundari, a housewife who has long participated in the world of community radio. The radio was named according to a combination of the names of their children and grandchildren, Adel and Lia. This radio broadcasts on the frequency of 105.2 FM. The radio is located right on the edge of the Pasinan village road whose community is composed of a majority of Osing people. Second, is Ayu FM, the newest community radio, founded in 2016. Ayu FM himself was inspired by the name of one of Pak Bayu's children. Ayu FM radio frequency is 94.6. The radio is located right on the edge of the sub-district highway with a mixed community environment including Osing and Java.

The third radio chosen was in the Rogojampi sub-district, to be precise, the village of Aliyan. The mixed community environment between Osing and Jawa radio is owned by Umi Zaski who works as a housewife. Javas FM radio, which is the same as Adelia and Ayu, comes from the name of one of Umi Zaski's grandchildren, Javas. Javas FM radio broadcasts on a frequency of 97.0, was founded in October 2018.

The broadcast hours of the three radios were almost the same, starting at 8:00 a.m. to 5:00 p.m. The requirements of establishing a radio has been met by each owner, by collecting 50 ID card and permission from the village to the district. However, the permits that have been obtained are still limited to temporary permits. If the Monitoring Office conducts a raid, the three community radios will automatically be subject to sanctions. Complaints about the difficulty of licensing and the high costs that must be incurred are the main factors complicating the process of obtaining a permanent legal permit. The radio of the Osing community does not broadcast hatred, it does not threaten the position of a regime or, more extreme, does not initiate a mass movement. However, the negative connotations attached to the radio community is a major barrier to their pursuit of formal legitimacy.

This claim of the social function of community radio displayed from the road to fame is one of the things community radio offers to fans and especially community radio artists who are directly involved in every broadcast program. Fame becomes even more attractive when fans and community radio artists/celebrities compete to continue to participate in every community radio broadcast. Community radio is inseperable from fans and artists. These two elements also depend on community radio. Popularity, is what they expect as fans and artists on community radio.

The popularity of this Osing artist can be seen by how often he appears in the local Banyuwangi media. The appearance of these regional artists at every opportunity always attracts public interest, and can certainly be included in the media coverage.

\footnotetext{
${ }^{22}$ M Featherstone, Posmodernisme dan Budaya Konsumsi (Yogyakarta: Pustaka Belajar, 2008).
} 
The same tribute goes to the $\mathrm{fans}^{23}$ of the community radio, apart from their own unique personal air name, broadcasters also did not hesitate to call up artist/celebrity ${ }^{24}$ to these fans. There are things that need to be underlined about diction, namely about being an 'artist' and 'popular', because with this popularity it is guaranteed that when he participates in broadcasts, fans and other artists will get to know him. In simple terms, the description of the meaning in the narrative above takes 'artist' and 'popular' as an important part, especially in how culture finds the context for cultural practice Stuart Hall, Representation 25.

The popularity of the Osing artist/celebrity is important in attracting other fans to the radio. Artists, fans, and radio are all part of the exchange of meaning to the individual to be included in a certain cultural environment. Heteronymy is an act of attracting attention and pleasing others ${ }^{26}$, with a concrete form called flirty. It can be explored about the 'ceriwis' itself as a style of speech that will later collaborate with action, flirtatious. The pattern of intercourse is more appropriate when it comes to choosing a more subtle word than flirtatious. "Flirtatious woman" is often identified with things that are not good, such as violating the norms of decency. However, this is what forms the uniqueness of community radio.

In short, the popularity status of the idol is assumed to be exchanged in a certain social space ${ }^{27}$. The fans and community radio artists wait for their momentum to move to a higher level. However, natural selection will later judge the appropriateness to a 'popular' concept .

Playing with stigma and social status becomes plural to make someone popular and worthy of appearing on the radio. Stories from a short message service that was read by radio broadcasters arbitrarily questioned the status of the artist who is performing. The word 'rondo' is explicitly used to eliminate the distance between fans and artists. Our culture can be interesting because of the combination of popularity and sex appeal ${ }^{28}$, this direct quote focuses on one of them regarding the role of sexuality. Ideally, women and men hold the same power in the discourse of sexuality. However, in the realities, the element of sex is often controlled by men.

The status of a widow, which is not considered in accordance with the nature of women, especially in Indonesia, because in this status it is not certain about the role of the family she has and the boundaries of being a woman which should have been blurred $^{29}$. In the case of Banyuwangi, researcher found that women with certain social and economic backgrounds, feel the sarcastic expression of gender more than general in

\footnotetext{
23 'fans' term for radio community listeners

24 'artist' term for radio community singers

${ }^{25}$ Stuart Hall, Representation (London: SAGE Publications, 2003).

${ }^{26}$ P Bordieu, Dominasi Maskulin (Yogyakarta: Jalasutra, 2010).

${ }^{27}$ A Heryanto, Budaya Populer di Indonesia (Mencairnya Identitas pasca Orde Baru) (Yogyakarta: Jalasutra, 2012).

${ }^{28}$ E Fromm, Seni Mencintai (Jakarta: Sinar Harapan, 1990).

${ }^{29}$ A. N Weintraub, Dangdut: Musik, Identias dan Budaya Indonesia (Jakarta: Kepustakaan Populer Gramedia, 2012).
} 
on air community radio. The word 'rondo' has a negative meaning which is interpreted as a married failure. It socially meant taboo to be presented in daily life discourse. Conversely, the word "rondo" became popular and is also used as magnetic term to attract community radio listeners. When artists and listeners use "rondo" in the radio interaction, they became famous by creating intimacy space.

\section{CONFIRMATION OF OSING LANGUAGE IN COMMUNITY RADIO}

Imagining the existence of language domination that emerged from the Using language that was present in almost every broadcast program. Then it was emphasized from the chosen song, to the communication between announcer-fan-artist on community radio, always using the Osing language. Unfortunately this is not an empirical condition. In fact when discussion happens in other languages beside Osing language, it still gets a place in the community radio. The Osing language does not necessarily negate the other languages, and can still be sidelined by them. Community radio is a multilingual media platform. When speakers of non-Osing languages can use fluently Osing language, they do not necessarily depart from their native language, it is a concrete form of cultural formation in Banyuwangi. Another form of the invasion of the Osing language on community radio can be seen through the Osing song, which is habituated and always plays. The latest old edition of Using songs does not escape the attention of listeners, both speakers of Osing languages or speakers of non-Osing languages. An negotiation between Osing language, Javanese and Madurese occurs when the process of repurposing is being re-constructed.

The process of accepting the Osing language to fans and community radio artists continued at the stage of acceptance of the Using language which was inseparable from the construction of Osing's identity which was formed in such a way as to create an understanding as a regional icon. Accompanied by the rapid progress in cultural policy, it increased the enthusiasm of people from different cultural segmentations to learn and use the Osing language.

The two radio owners, Ayu FM and Javas FM, said that in the places they were broadcasting, efforts were made to use the Osing language. Rather, most of the nonOsing listeners were able to understand what the announcer was saying. The limitation of language mastery cannot be seen when the fans and artists are involved in the atmosphere of conversation or reply to messages directly while singing in Osing language. Even though it still sounds stiff and less flexible.

In the pronunciation of kelendi, apuwo, are still read in the default language of the audience, Javanese, in Osing the ' $u$ ' suffix is read 'au' and the ' $i$ ' suffix is read by adding 'ai'. There was a slight nasal discharge at the end of the word. In Javanese the tendency for ' $u$ ' to become ' $o$ ', makes a clear difference when Javanese try to use Osing which in their daily life they don't often use as a daily conversation. Several times the writer saw the stiffness of this Osing accent which sounded strange while being spoken, but all seemed to have left no mark when they sang a song. The nature of the song awakens 
their pent-up obsession. Wandering on a radio that was not located between the majority of the Using settlers presents a new perspective on the almost complete acceptance of the Using language in Banyuwangi.

\section{VI. "CEMEPLOS"AND "NGUDANG": GESAH" THE OSING ON THE BROADCAST}

Javas FM radio catchphrase is Gawe tentreme Ati. The catchphrase Nyendal nong ati attached to Adelia FM as an affirmation of intimacy. The catchphrase Ademm dulur used by Pak Bayu, the owner of Ayu FM, seems to mean a collective space. It is important to analyze the imagination in the social space formed from the three radios, especially in relation to social communication media. Gesah in Osing Banyuwangi is interesting because it is directly related to the daily routine of broadcasting on community radio. The conversations that occur between fans-artists-broadcasters on community radio are a form of Gesah .

The origins of the word is formed and expressed as an infiltration of social circumstances with slight modifications that always involves a sense of the body ${ }^{31}$. This form is seen in a few words in Osing, kampah (stop by) the uptake of the English language come here, nderongos (danger) is also an absorption from English dangerous, awak (me) is an absorption from Malay, ancik (copulation) is also an absorption from Malay, peces (money) is an uptake of Javanese from the Majapahit era. Some of these words illustrate that Osing's vocabulary is also processed and adds to the vocabulary by interacting and exchanging meanings with other languages.

Arps $^{32}$ mentions that cemeplos says what it is spontaneously with a variety of languages or certain vocabulary. These broadcasters are accustomed to open language and coincidentally the hierarchical language of Osing is different from Javanese which is divided into Inggil, Madya and Ngoko. In particular, Osing language addressed the spirit of egalitarian which can be use by listeners and artists. The cheering session is also available in the broadcast segmentation on community radio.

Speaking without further ado is a form of communication in the Osing language. 'Tasemak' or glasses in Indonesian equated with the faces of both the fans and the artists, Duki and Typhoon, did not cause a negative excess to the next conversation. This intimacy was even greeted by jokes about their faces which were likened to the sight, which is round, has glass and is often used by parents.

\footnotetext{
${ }^{30}$ Gesah in Indonesian means conversation

${ }^{31}$ Walter J Ong, Kelisanan dan Keaksaraan (Yogyakarta: Perpustakaan Nasional: Katalog Dalam Terbitan, 2013).

32 Arps, "Terwujudnya bahasa Using di Banyuwangi dan peranan media elektronik di dalamnya ( selayang pandang, 1970-2009)."
} 
In oral culture, learning or knowing means achieving familiar and empathic communal identification with the known, in other words 'living'33. The term in Osing is called Ngudang. This term is usually used to cradle toddlers, in this context Ngudang can be interpreted to entertain, make the other person feel more cared for and make the situation pleasant. Ngudang sessions were also found on community radio in the data obtained from broadcast transcripts.

The expression of sympathy or Ngudang in Osing's term is part of the conversation in this context is to pay more attention to the other person. 'Berai' is distinctly different from lust. 'Berai' is a high level of painstaking, an action taken by the individual. Sacrificed some things for others so that Ngudang appeared as the climax of a sympathetic greeting that was the same as saying thank you.

Community radio artists also come from a similar social character. Even when they work as a laborer, informal traders, or other professions, they are still taking time to entertain themselves and others by singing. This does not paint them as lazy, wasting time, or unproductive. At first glance, the language of authority conveyed by the festival is a form of discipline, creativity, and significant benefits that can be obtained in the future. These artists, outside their working time, will stop by the radio to help their brothers to turn the economy back.

An abreacting (release of emotion) can be embodied in the form of words and movements; it aims to reduce tension ${ }^{34}$. Sounding out as a form of tension release is common. However, it is more effective when the release of tension through sound is conveyed through a particular medium. Community radio is a suitable medium for singing and communication to channel tensions in everyday life.

Maintaining a balance so that the others can also earn that day is an important aspect of community radio. It is not uncommon when the radio is quiet and the broadcasters are alone, for artists to voluntarily come and sing, even though they have to leave their jobs, leave their shops, suspend calls from their client's work orders. The sense of togetherness and community that has been built around them singing should not be twisted to become a scapegoat for the various negative things that accompany community radio. Artists paid for their performance, they are not lazy people with all the slanted labels that the language of authority carries.

Radio is an easily accessible medium that does not require much adaptation to use. This medium offers programs that are favored by fans and artists, for singing and broadcasting. To fulfill the quality as an announcer or singer, you don't have to go through a process that takes so long, this happens naturally. Tension relief can work best with a minimal process flow. Listening to each other or sharing stories, jokes through radio media are done every day by community radio artists and broadcasters.

Their humor and conversations on community radio are far from being as shocking as horror stories. Conversation flows interspersed with fellow artist humor can reduce fragmentation of social status. Intimacy is awakened through the

\footnotetext{
${ }^{3}$ Ong, Kelisanan dan Keaksaraan.

${ }^{34}$ Fromm, The Art ofListening (Kritik Atas Psikoanalisis Sigmund Freud).
} 
feeling of being equal in social position and for music. In community radio people can share information and reminisce together. Audio is by no means their limit, even though visually they don't see the other person.

Media is a message ${ }^{35}$. Ong sees the role of the media as messengers that develop from oral culture. The messages scattered by community radios as speakers of local languages have not yet been able to easily penetrate the language of authority in the form of writing and sometimes movement so that it tends to be complicated in equating future perceptions about whether or not community radio is in Banyuwangi.

\section{LANGUAGE DIVERSITY ON COMMUNITY RADIO}

The incompatibility of understanding language can be minimized if the interpreter understands that the location of language is between forms and ideas ${ }^{36}$. However, it must be understood when language is arbiter, it is not necessarily correlated with the empirical object. In other words, language is based on social consensus. which means. When the language is formed, all the structures are contained within the language. The structure and system of linguistics will produce or rather than force a consensus on the meaning of language. Thus, in the use of language, the concept (Signified) becomes one that changes historically and interchangeably between different cultural concepts, as well as differences in historical moments to be classified and initiates a view on differences Hall.

$$
\begin{aligned}
& \text { "I am Mr. Mismun, in here (radio) is called Panji Tawang (they) all know it" } 37 \\
& \text { "Yes (air name) still use Brodin"38 }
\end{aligned}
$$

Two names that tend to be foreign to Osing's ears and are rarely used in Osing's naming. The two air names are used by Mr. Brodin whose ethnic is Madura and Mbah Mismun whose ethnic is Javanese. The fans and the artist community radio understand that Panji Tawang is Javanese and Brodin is Madura. The adaptation of these two ethnicities in the Osing language seems to have succeeded in convincing the Osing people that the Osing language is not only for the Osing people but for immigrants who live permanently in Banyuwangi. (Belongingness) ${ }^{39}$

\footnotetext{
${ }^{35}$ Ong, Kelisanan dan Keaksaraan.

${ }^{36} \mathrm{R}$ Barthes, Elemen-elemen Semiologi (Yogyakarta: Jalasutra, 2012).

${ }^{37}$ Interview with Mr. Mismun/artist of Ayu FM. Date: 7 February 2019

${ }^{38}$ Interview with Mr. Brodin/artist of Javas FM. Date: 24 August 2019

39 According to Arps belongingness in cultural matters for every individual who believes himself to be part of a cultural identity regardless of if the individual comes from outside the region Bernard Arps, "Osing Kid and The Banners of Blambangan: ethnolinguistic identity and the regional past as ambient themes in an East Javanese town," Academia Vol.1l, no. Wacana (2009): 1-38.
} 
"I made a rhyme, tung duak telok empat terus jejen nok manok an/mon tak endek duli ngocak Brodin ngok congok an (jokes in Madurese), everyone was laughing when I sent it. If the original Madurese were on the radio, everyone laughed. You try it. " "40

That the recipient of the message is as important as its message when the marker (Signifier) given has been encrypted (Endcode) and already contains a meaning, it must first be interpreted slowly (Decode) by the recipient Hall. There is a next stage of Endcode-Decode, namely interpretation, so that the same meaning appears. Regarding the poem written when Mr. Brodin sent an SMS on the radio which saying something like, "one two three four snacks, if you want it say it, if not, Brodin is space out at the door". For those who fully understand it, it will be a funny joke. However, if the recipient of the message is not able to master the concept and sign, listening to a foreign code (language) will confuse the meaning he has. Mr. Mismun tried to introduce himself as a person with a Javanese background through his chosen air name, Panji Tawang, a name formation sent to fellow fans and community radio artists, especially on Ayu FM.

The endcode process (encoding) in a certain language speech with an inherent structure must be slowly interpreted (decode) to the recipient of the message because the sender of the message must be in the position of the recipient of the message, not only with a single status as the sender of the message. Avoid the blurring of language that can occur when the sender is not positioned as the recipient of the message. This obfuscation can get worse when the narrative about language and everything related to it has been presented beforehand without any room for negotiating ideas and meanings.

This interpretation is carried out by external processes, observing and adding vocabulary. The endcode process in entering information in the message must be balanced with the decode that will be carried out by the recipient of the message. The incomprehension, negative justification, and distance created regarding the emergence of popular culture are precisely because these two processes go hand in hand and in the system. The parties who have the task of sending messages cannot channel external assistance to the recipient of the message as the final stage of the interpretation process

Community radio and the subjects participating in it should be made available by opening up a space for negotiation which in turn results in an entirely new reading and writing. The public will not be led to the same perception of community radio and the subjects that participate in it as a negative thing. Another alternative for the community to respond to the transformation of Osing 's increasingly religious culture, adding cultural variables that are not limited to traditional ceremonial heritage, traditional clothes but also seeing inheritance through language with the appropriate medium so that it can be categorized that Osing community radio is a cultural development disparity.

\footnotetext{
${ }^{40}$ Interview with Mr. Brodin/artist of Javas FM. Date: 24 August 2019
} 


\section{CONCLUSION}

Osing who appeared was Osing who carried a heterogeneous locality identity because it did not appear singularly. There is a communal segment on community radio that touches grassroots people in a region, even though they come from different cultural backgrounds. Osing, who is the representative on community radio, is Osing who is not branded according to the rules of the regional elite. When the stigma of Osing's women is clearly displayed in the community radio broadcast segmentation. The stereotype of fans and community radio artists has become negative, one of which is the existence of the nickname rondo which is often pinned to female fans and artists. The opportunity offered by community radio is to gain popular status, a dream come true in grassroots communities. Gesah which is a form of speech present with Cemeplos (to speak frankly) and Ngudang (a sentence intended to attract the interlocutor) is used by fans, artists and community radio broadcasters. Community radio also has a significant role in the continuity of language diversity apart from Osing in community radio, namely Java and Madura.

This research is also intended to address the issue of bureaucrats and cultural elites who are currently new professions along with cultural policies in Banyuwangi. The group should be able to maximize the use of social spaces that can create cultural economic opportunities. Furthermore, the issue of inequality, inherent in the festivals in Banyuwangi, has created ripples when the benefits of all of this are only enjoyed by a few of parties. Under these conditions, community radio has established itself as a space capable of creating social bonds.

\section{ACKNOWLEDGMENT \\ None \\ COMPETING INTEREST \\ None}

\section{REFERENCES}

Anderson, B. (2008). Imagined Communities (Komunitas-Komunitas Terbayang). Insist.

Arps, B. (2009). Osing Kid and The Banners of Blambangan: ethnolinguistic identity and the regional past as ambient themes in an East Javanese town. Academia, Vol.11(Wacana), 1-38.

Arps, B. (2010). Terwujudnya bahasa Using di Banyuwangi dan peranan media elektronik di dalamnya (selayang pandang, 1970-2009) [ The realization of the Using language in Banyuwangi and the role of electronic media in it (at a glance, 1970-2009)]. Tokyo Research Instituties for Languages And Cultures Of Asia and Africa (ILCAA) Tokyo of Foreign Studies, 226-245.

Barthes, R. (2012). Elemen-elemen Semiologi. [Semiological Elements]. Jalasutra. 
15 | The Journal of Contemporary Sociological Issues

Bourdieu, P. (2010). Arena Produksi Kultural. [Masculine Dominance] Pustaka Pelajar.

Collin, M. (2003). Serbia Calling: Kisah Radio B92, Musik Rock' n' roll dan Perlawanan Bawah Tanah dari Beograd. [Serbian Calling: The Story of Radio B92, Rock ' $n$ ' Roll Music and Underground Resistance from Belgrade]. Kantor Berita Radio 68H.

Featherstone, M. (2008). Posmodernisme dan Budaya Konsumsi. [Posmodernisme dan Budaya Konsumsi]. Pustaka Pelajar.

Fromm, E. (2002). The Art ofListening (Kritik Atas Psikoanalisis Sigmund Freud). Immortal Publishing dan Octopus.

Fromm, Erich. (1990). Seni Mencintai. Sinar Harapan.

Hall, S. (2003). Representation. SAGE Publications.

Heryanto, A. (2012). Budaya Populer di Indonesia (Mencairnya Identitas pasca Orde Baru). Jalasutra.

Jurriens, E. (2009). From Monologue To Dialogue: Radio And Reform In Indonesia. Leiden: KITLV Press.

Kirschke, L. (2004). Gelombang Kematian: Media Pengobar Genosida Rwanda. [Waves of Death: Media of the Rwandan Genocide]. KataKita.

Komariah, K. (2014). Pemanfaatan Radio Komunitas Di Masyarakat Nelayan Dalam Melestarikan Lingkungan Pantai Berbasis Budaya Lokal'. [ Utilization of Community Radio in Fishing Communities in Preserving Local Culture-Based Beach Environment]. Jurnal Visi Komunikasi, 13(1).

Makmur, M. H., \& Taufiq, A. (2015). Relasi Aktor Dalam Ruang Wacana Kebijakan Kebudayaan Di Banyuwangi. KARSA: Jurnal Sosial Dan Budaya Keislaman, 22(2), 235. https://doi.org/10.19105/karsa.v22i2.575

Mohamad, G. (2018). Seni Politik Pembebasan. [The Political Arts of Liberation]. Yogyakarta: IRCISoD.

Ong, W. J. (2013). Kelisanan dan Keaksaraan. [Ordinance and Literacy]. Perpustakaan Nasional: Katalog Dalam Terbitan.

Prasetyo, H. (2016). Image Hegemonik: Membentuk dan Menciptakan Ruang Reproduksi Kultural', [Hegemonic Image: Shaping and Creating Spaces for Cultural Reproduction] dalam Kebudayaan Osing : Konstruksi, Identitas Dan Pengembangannya. Anoegrajek.

Prasetyo, Hery., \& Rosa, D. V. (2015). Reinterpreting The Political Fragmentation of Cultural Space.

Prasetyo, Hery. (2017). Ruang Abstrak Pemangku Adat: Narasi Elite Dan ReTradisionalisme Komunitas Using. [Abstract Space for Adat Leaders: Elite Narrative and Re-Traditionalism of the Using Community]. Jurnal Sosiologi Pendidikan Humanis, Volume 2, 74-87.

Prasetyo, Hery, \& Rosa, D. V. (2014). Space For Cultural Articulation: Voicing The Local In 
16 | On Air: Representing Osing Identity in Community Radio

Commodity Transformation. 1-12.

Sutrisno, M., \& Putranto, H. (2005). Teori-Teori Kebudayaan. [Cultural Theories]. Kanisius.

Tacchi, J. A. (1997). Radio Sound As Material Culture In The Home', University College London. University of London.

Wahyudiono, Andhika. (2018). Kajian Bahasa Osing Dalam Modernitas [The Study of Osing Language in Modernity]. Dalam Eskplorasi Bahasa, Sastra dan Budaya Jawa Timuran. Jember: Universitas Jember[In Exploration of East Javanese Language, Literature and Culture. Jember: University of Jember],

Weintraub, A. N. (2012). Dangdut: Musik, Identias dan Budaya Indonesia. [Dangdut: Music, Identity and Indonesian Culture]. Kepustakaan Populer Gramedia. 